\title{
THE FUTURE OF WORK AND WOMEN
}

\author{
Ewa Lisowska*
}

\begin{abstract}
:
The paper analyses the causes of the current situation of women on the labour market in Poland, the Czech Republic and Slovakia as well as women's chances for the future. It discusses the questions: Are women more at risk of unemployment than men in the future, or less? Will the twenty first century favour the development of women's career opportunities? The conclusion is that we are facing the end of industrial era and are moving towards the era of information and knowledge. Women are more prepared for these changes, as they are better educated, they are motivated to take up new challenges, and they posses the skills needed in new economy like the ability to communicate and cooperate, empathy and intuition.
\end{abstract}

Keywords: discrimination against women; employment for women; equal opportunities; flexible employment; labour market; skills for the future; stereotypes

JEL Classification: B54, J16

\section{Situation of Women on the Labour Markets in Poland, the Czech Republic and Slovakia}

\subsection{Macroeconomic Context}

The data concerning the increase in gross national product indicate that the Czech Republic is a country with the most dynamic economic development - in 2005 its GNP per capita reached $73 \%$ of the Community average, i.e. more than in Portugal $(71.4 \%)^{1}$. Despite slower pace of development of the Czech Republic as compared to two other countries in the first years of transformation, over the last few years their economy has accelerated, inter alia due to reduction of labour costs (in case of Slovakia and Poland these costs have increased $)^{2}$.

In 2005, Poland and Slovakia have lower economic indicators, although there were years of their intensive growth (1994-1999), when gross national product was increasing at the rate of 4-6\% annually. Such a high growth was caused mainly by the growing number of small and medium private businesses and inflow of foreign

* Warsaw School of Economics, Warsaw (ewa.lisowska@sgh.waw.pl)

This report could be possible to appear thanks to the Heinrich Boell Foundation in Poland. See:

E. Bendyk, E. Lisowska, The Future of Work, Fundacja im. Heinricha Bölla, Warsaw, December 2006.

1 Information from "Gazeta Wyborcza" of 14.01.2006 presented on the website http://wiadomości.gazeta.pl

2 Based on the report of the World Bank. See: Growth, Employment and Standards of Life in Poland at the Period of Accession, Report No 28233-POL, World Bank, Warsaw 2004, p. 32. 
investments. As a result, employment was increasing, while unemployment rate was declining, however, not as fast as it might have been expected. Both countries show much higher tendency towards non-employment economic growth than the Czech Republic. $^{3}$

The available statistical data for Poland indicate that participation of women in creation of gross national product is lower than men's (respectively 40 and $60 \%$ ), the similar situation is observed in respect to the real GNP per capita created by women and men (respectively: 8,192 and 12,530 USD). ${ }^{4}$

Women comprise almost a half of the total number of the employed ( $46 \%$ in Poland and in Czech Republic, $43 \%$ in Slovakia; average for the old EU countries is $43 \%)^{5}$. The majority of women are employed in education and health care, i.e. sections belonging to the non-productive ones, maintained from the state budget or municipalities, with the lowest remuneration. At the same time, these are key sections as regard social security and development of knowledge society.

The unsolved problem remains the lack of the statistical data on unpaid work in households, agricultural farms, or family service businesses usually performed by women. So far, that work does not exists from the economic point of view, as it has no market price. Nevertheless, the surveys carried out in Poland at the end of the nineties indicated that the average time spent on housework amounts to 5.5 hours in urban areas and 6.5 hours in rural areas; recalculated into money, value of housework equals average monthly remuneration in the national economy. The goods and services produced in a household increase the value of consumption by about $27 \%$, while in case of gross national product by about $23 \%{ }^{6}$

In situation when we deal with the employers' market, i.e. labour supply is higher than demand for labour, women's access to employment is hindered due to the fact that employers perceive them in the context of family responsibilities. There are evident symptoms of unequal treatment of women in the sphere of employment in Poland, the Czech Republic and Slovakia, despite implementation of the Community's legislations forbidding discrimination into the legislature of these countries.

3 See: W trosce o pracę, Raport o rozwoju społecznym. Polska 2004 [Concern for Employment. Report on Social Development], UNDP, Warsaw 2004, pp. 94-95.

4 Data for 2001, see: W trosce o pracę, Raport o rozwoju społecznym... [Concern for Employment. Report on Social Development], op. cit., part: Wskaźniki rozwoju społecznego [Social developments indicators], p. V.

5 Own calculations based on Statistical Yearbook CSO, 2005, p. 230; Statistical Yearbook of the Czech Republic 2005, p. 89 oraz Statistical Yearbook of Slovakia, p. 319.

6 B. Mikuta, Studia nad wartością pracy domowej w mieście i na wsi ze szczególnym uwzględnieniem realizacji funkcji żywieniowej, praca doktorska wykonana w Katedrze Organizacji i Ekonomiki Konsumpcji, pod kier. nauk. dr hab. K. Żelaznej [Studies on the Value of Housework in Urban and Rural Areas with Particular Regard to Realization of Nutritional Function. PhD dissertation written in the Chair of Organization and Economics of Consumption, under the methodological tutoring of PhD K.Żelazna, SGGW, Warszawa 2000. The newest results of empirical surveys are presented in: A. Titkow, D. Duch-Krzysztoszek, B. Budrowska, Nieodpłatna praca kobiet. Mity, realia, perspektywy [Unpaid Work of Women. Myths, Reality, perspectives], Published by IFiS PAN, Warsaw 2004. 


\subsection{Manifestation of Discrimination against Women in Employment}

Low Employment Rates, High Unemployment Rate. Employment rates for both sexes are in Poland and Slovakia lower than the average for 25 EU Member Countries, while in the Czech Republic - they are close to the average, and in case of men they are even higher than Community's average (see Table 1). Among the countries with the highest employment rates of women belong Denmark $(72 \%)$, the Netherlands $(66 \%)$, Sweden (71\%), Finland (66\%) and the United Kingdom (66\%). Poland has one of the lowest employment rates of women in the EU. The lower rates than in Poland are observed only in Italy, Malta and Greece.

Table 1

Employment Rates by Sex in Czech Republic, Poland and Slovakia and the EU, 2004 (in \%)

\begin{tabular}{|l|c|c|}
\hline Country & Women & Men \\
\hline EU (25 countries) average & 55.7 & 70.9 \\
\hline Czech Republic & 56.0 & 72.3 \\
\hline Poland & 46.2 & 57.2 \\
\hline Slovakia & 50.9 & 63.2 \\
\hline
\end{tabular}

Source: Eurostat, Labour Force Survey. Based on Situation of Women. International comparisons, Report 13, p. 14; http://www.monitoring.rownystatus.gov.pl

The important social problem in Poland and Slovakia is high unemployment, the highest among the EU countries (see Table 2). The lowest rates of unemployed women are observed in Ireland (3.9\%), the United Kingdom (4.2\%) and the Netherlands $(4.8 \%)$.

Table 2

Unemployment Rates by Sex in Czech Republic, Poland and Slovakia and the EU, 2004 (in \%)

\begin{tabular}{|l|c|c|}
\hline Country & Women & Men \\
\hline EU (25 countries) & 10.2 & 8.1 \\
\hline Czech Republic & 9.9 & 7.1 \\
\hline Poland & 19.7 & 18.0 \\
\hline Slovakia & 19.3 & 17.0 \\
\hline
\end{tabular}

Source: Eurostat, Labour Force Survey. Based on Situation of Women. International comparisons, Report 13, p. 15, http://www.monitoring.rownystatus.gov.pl

In case of Poland, low employment rates of women are to a great extent caused by a shortage of institutional forms of childcare. The Lisbon strategy recommends establishing conditions for including $90 \%$ of children at the age between 3 years and beginning of school in kindergarten care by the year 2010, while pre-kindergarten care (crèche) should cover $33 \%$ children at the age below 3 years ${ }^{7}$. In Poland, the number of kindergartens significantly decreased during the period of transformation: from almost

7 U. Sztanderska, Rynek pracy dla konkurencyjnej gospodarki, w: Biała Księga 2004 [The Labour Market for Competitive Economy, in the White Book, Polish Forum for the Lisbon Strategy], Polskie Forum Strategii Lizbońskiej, Gdańsk-Warszawa, maj 2004, p. 197. 
27 thousand at the end of the eighties to 8,175 in the year 2001/2002 (per 1 million 223 thousand children aged 3-5 years). In urban areas about $50 \%$ of children participate in the kindergarten care, while in rural areas - only 14\%. The average indicator for Europe amounts to $80 \%{ }^{8}$ Among the analysed countries, the Czech Republic have the highest rate of children participating in preschool care and the highest employment rate of women. ${ }^{9}$

Demographic situation of Poland, Czech and Slovakian is characterised by a diminishing number of concluded marriages, declining fertility and progressive ageing of the society. Young people, school leavers think firstly about finding a good job, while they postpone decisions concerning marriages and parenthood. Over the years 1992-2003, the number of concluded marriages per 1,000 of population dropped decidedly in the Czech Republic - from 7.18 to 4.79 and in Slovakia - from 6.39 to 4.83; the lowest drop was observed in Poland: z 5.66 do 5.12. ${ }^{10}$ Women have their first child evidently later: on average at the age of 27 years in Slovakia and 28 years in Poland and the Czech Republic, while in 1991 the average age of women at the birth of the first child was 25 years in the Czech Republic and Slovakia and 26 years in Poland. ${ }^{11}$

The hindered access to institutional forms of childcare limits occupational activation of women, it also has a negative impact on procreative decisions. In the countries that carry out the policy of equal rights for both women and men, including reconciliation of work with family life (e.g. in Sweden where kindergartens are free of charge and parental leave is shared by mothers and fathers) fertility rate (the average number of children per a woman at the age 15-49) is higher than in the countries of the Central and Eastern Europe: in Sweden in amounts to 1.65, in Finland 1.72, in Norway 1.75 , while in Poland only 1.24, in the Czech Republic 1.17, in Slovakia 1.10. ${ }^{12}$

Women earn less. Discrimination against women is reflected in on average lower female pay received for work of the same or similar quality. Lower remuneration of women than men are observed in each country and in each occupational group. At the same time, the low level of potential earnings that a woman may obtain through work negatively influences her economic activity, investment in herself through improving qualifications and obtaining new skills.

8 E. Nowakowska, Powiedz Jasiu, powiedz Olu, „Polityka” nr 6, z 8 lutego 2003. See also: W trosce o pracę ...., op. cit., p. 38.

9 W trosce o prace ..., op. cit., p. 36. According to the American estimates, investing in the preschool care is economically profitable. Each 1,000 dollars spent on kindergartens is repaid seventh times, as the children who participate in the preschool institutional care have better results at school, they are more successful at work, and they earn more, which means, that they pay higher taxes, and less often have to use health care services (See: I. Lazar, R. Darlington, The Lasting Effects of Early Education: a Report from the Consortium for Longitudinal Studies, "Journal of the Society for Research in Child Development" 1982, No 47).

10 Based on: Europe in Figures, Eurostat Yearbook 2005, p. 68.

11 Ibidem, p. 72. In the EU-15 countries it is close to 30 years.

12 Data for 2002 come from: I. E. Kotowska, Proces starzenia się ludności Polski do 2030 r. - opis i jego percepcja społeczna, w: Później na emeryturę?, Niebieskie księgi 2004, Rekomendacje nr 16, Instytut Badań nad Gospodarką Rynkową, Gdańsk 2004, p. 17. The data of the Statistical yearbook of Sweden 2006 indicate that fertility rate in 2004 increased to 1.75 (Statistical Yearbook of Sweden 2006, p. 101). 
Table 3

Differences in Average Remuneration of Women and Men in the Czech Republic, Poland and Slovakia and the EU, 2004 (in \%)

\begin{tabular}{|l|c|}
\hline Country & Average difference in \% \\
\hline$E U(25$ countries $)$ & 15 \\
\hline Czech Republic & 19 \\
\hline Poland & 16 \\
\hline Slovakia & 23 \\
\hline
\end{tabular}

Source: Eurostat, Labour Force Survey. Based on Situation of Women. International comparisons, Report 13, http://www.monitoring.rownystatus.gov.pl

The highest gap in earnings concerns Slovakia, slightly lower the Czech Republic, while the lowest differences are in Poland (see Table 3). The analysis of the detailed statistical data for Poland leads to conclusion that relatively largest difference in remuneration concerns managerial positions and tertiary education - women in these groups earn even by $30 \%$ less than men.

Why women earn less, despite the fact that their formal education is on average higher than that of men? Analysing the problem in the historical context, women entered the labour market as worse educated, i.e. cheaper labour force. The treatment of women as cheaper labour force, and jobs performed by them as easier, less prestigious and less strenuous has been imprinted in the social consciousness.

Seen from the macroeconomic point of view, the differences in female and male remunerations are caused by:

- occupations segregation and feminization of occupations (in the so-called "female occupations" remuneration is by definition lower than remuneration in the so-called "male occupations")

- the low number of women holding the top, best paid executive managerial positions due to the glass ceiling, i.e. barriers hindering promotion of women for such positions

- prejudices (stereotypes) concerning perception and evaluation of women's qualifications as less significant for the economy than qualifications of men

- lack of national mechanisms that would counterbalance negative influence of prejudices and cultural factors, and would promote and control obeying the law within the area of equal rights for women and men in employment.

On the microeconomic level (enterprise) among the reasons for lower female remuneration should be counted the following ones: women are placed on the lower positions of remuneration tables, they earn less than their male counterparts in a given position, they are promoted much slower (financially in hierarchy of positions), women's work is usually evaluated lower, while descriptions of work positions are incomplete and very general, they do not include such skills, as holding responsibility for others, manual skilfulness, caring for other people, good self-management, interpersonal communication, intuition.

Notwithstanding the fact that there is decreasing tendency in the difference of female and male remuneration in all countries (e.g. in Poland in 1998 the gap amounted 
to $30 \%$, in 2003 to $18 \%$, and in 2004 to $16 \%$ ), it may be still observed, also for work of the same quality.

Difficult access of women to managerial positions. Working women are better educated than working men; there are more women than men among tertiary school students (see Table 4). Moreover, women possess skills that fit very well in the modern business: interpersonal skills - teamwork, communication skills, negotiating in winning-winning categories, as well as intrapersonal ones - emotional intelligence, nevertheless, their numbers among the top executive managers - directors and company presidents are very low. ${ }^{13}$

Table 4

Women among Tertiary School Students in the Czech Republic, Poland and Slovakia and on average in the EU, 2003

\begin{tabular}{|l|c|c|c|}
\hline \multirow{2}{*}{ Country } & \multicolumn{3}{|c|}{ Percentage of women among } \\
\cline { 2 - 4 } & Total of students & $\begin{array}{c}\text { Students of maths } \\
\text { and computer science }\end{array}$ & $\begin{array}{c}\text { Students of } \\
\text { engineering fields }\end{array}$ \\
\hline$E U-25$ & 55 & 36 & 24 \\
\hline Poland & 57 & 42 & 20 \\
\hline Czech Republic & 51 & 34 & 19 \\
\hline Slovakia & 53 & 34 & 28 \\
\hline
\end{tabular}

Source: Europe in Figures, Eurostat Yearbook 2005, p. 101.

Women lack collective experience in maintaining managerial positions; they do not have the network of contacts, they do not have mentors, but they are surrounded by social prejudices claiming they are not as well suited for management as men.

Relatively the largest number of women is observed on the lower managerial positions. In Poland women constitute 1/3 among the total number of managers, similarly to Slovakia, while in the Czech Republic their share is lower $-28 \%$. The highest percentage shares of women holding managerial positions are observed for Lithuania (41\%), Latvia (38\%) and Ireland (39\%).

Table 5

Women and Men in Managerial Positions in the Czech Republic, Poland and Slovakia and on average in the EU, 2003

\begin{tabular}{|l|c|c|}
\hline Country & Percent of women & Percent of men \\
\hline EU $(25$ countries $)$ & 30 & 70 \\
\hline Poland & 33 & 67 \\
\hline Czech Republic & 28 & 72 \\
\hline Slovakia & 34 & 66 \\
\hline
\end{tabular}

Source: European Commission DG EMPL, see Situation of Women. International Comparisons, Report 13, p. 14, http://www.monitoring.rownystatus.gov.pl

13 There is lack of statistical data on participation of women among the top executive managers for the discussed countries. For example in the Netherlands this share comprises $7 \%$, but in other countries it is lower: from $1 \%$ to $5 \%$ (based on the material obtained during the study visit in the Netherlands on 19-20 April 2006). 


\subsection{Own Business as a way to Escape from Discrimination and Glass Ceilings}

The threat of unemployment and lower chances for employment in the formal sector are one of the significant reasons for women's interest in becoming self employment. The Labour Force Survey 2004 indicates that among the total number of the self-employed, women constitute $35 \%$ in Poland and $26 \%$ in both: the Czech Republic and Slovakia. ${ }^{14}$ In all three countries women took advantage of the chances that appeared at the beginning of the nineties and established their own businesses more often than men.

In case of Poland there is a high share of the women-owners of private agricultural farms among women entrepreneurs (it is also true for men), as comparing to the other countries, the participation of agriculture in the Polish economy is significantly higher than in Slovakia or the Czech Republic (see Table 6).

Table 6

Structure of Employment by Sectors in the Czech Republic, Poland and Slovakia and the EU, 2003

\begin{tabular}{|l|c|c|c|}
\hline Country & Agriculture and related & Manufacturing & Services \\
\hline$E U-25$ & 5.3 & 28.3 & 66.4 \\
\hline Poland & 18.2 & 28.5 & 53.2 \\
\hline Czech Republic & 4.5 & 39.9 & 55.6 \\
\hline Slovakia & 6.0 & 38.1 & 55.8 \\
\hline
\end{tabular}

Source: "Rzeczpospolita” of 6.12.2004.

The surveys carried out inter alia in Poland ${ }^{15}$ and in Bulgaria ${ }^{16}$ indicate that women business owners are usually women aged 40 years or more, married, usually with one or two brought up children and long standing experience in occupational work in the public sector. Male entrepreneurs are also persons in their forties but as compared to women there is lower share of unmarried men among them. With the exception of agriculture where persons with low education dominate, the share of women entrepreneurs with vocational secondary, post-secondary or tertiary education is high. ${ }^{17}$ Comparison of women and men entrepreneurs in respect to educational level does not indicate any significant differences.

While men entrepreneurs usually comprise technicians and engineers, and then qualified workers, women business owners more often comprise economists, humanists

14 Own calculations based on the Statistical Yearbook of Poland 2005, p. 233, Statistical Yearbook of the Czech Republic 2005, p. 92 and Statistical Yearbook of Slovakia 2005, p. 320.

15 Por.: E. Lisowska, Przedsiębiorczość kobiet w Polsce na tle krajów Europy Środkowej i Wschodniej, „Monografie i Opracowania” nr 494, Szkoła Główna Handlowa, Warszawa 2001, p. 55-58.

16 A. Stoyanovska, Jobs, Gender and Small Enterprises in Bulgaria, Series on Women's Entrepreneurship Development and Gender in Enterprise, Working Paper No 20, International Labour Office, Geneva 2001.

17 Relatively high level of education of women entrepreneurs is a norm for the entire Europe, which is indicated by the results of many surveys, e.g. the survey of 2004 carried out among the women members of the Eurochambres in all 25 EU countries; http://www.eurochambres.be/women/index.htm. 
or are without any particular occupation, i.e. with general secondary education. There are also observed differences in profiles of conducted activity. Profiles of activity of men entrepreneurs concentrate on four branches: trade, construction, manufacturing and transport, while profiles of activity of women are more dispersed: they most often concern trade, and then various services, including business related ones (bookkeeping, public relations, consulting, office interior design).

Making a decision concerning starting own company is more difficult for women as more often than men they have to overcome their own fear of failure, lack of faith in success, and apprehension concerning their ability for such work. They therefore need psychological support and specific aid. Such aid is offered only by non-governmental organizations, while there is a lack of governmental programmes promoting entrepreneurship among women in Poland, the Czech Republic and Slovakia. In Poland, there operates the Agency for the Development of Entrepreneurship, as in Slovakia, but has no special offers for women.

On the background of the European Union countries, Poland distinguishes relatively high participation of women among the self-employed (see Table 7), as well as the share of women entrepreneurs among the total number of the employed women $-25 \%$ as compared to $7 \%$ in Slovakia, $11 \%$ in the Czech Republic and $11 \%$ for the old EU countries $(15){ }^{18}$

Table 7

Participation of Women among the Total Number of the Self-Employed in the Selected Member States of the European Union

\begin{tabular}{|l|c|}
\hline Country & Share in percents \\
\hline Austria & 34.2 \\
\hline Belgium & 27.7 \\
\hline Czech Republic & 27.2 \\
\hline Denmark & 20.8 \\
\hline Finland & 32.8 \\
\hline Spain & 26.8 \\
\hline Ireland & 24.9 \\
\hline Germany & 27.8 \\
\hline Sweden & 25.6 \\
\hline United Kingdom & 26.5 \\
\hline POLAND & 36.3 \\
\hline
\end{tabular}

Source: Financing Women Entrepreneurs, OECD Small and Medium Enterprise Outlook, Geneva 2000, pp. 53-63.

On the one hand, it is caused by the women's determination when facing limited job opportunities in the formal sector due to the fact that in the situation of a high labour supply the employers prefer male candidates who are more available and traditionally

18 Women and men on the labour market, Central Statistical Office, Warsaw 2004 and Statistical Yearbooks of Slovakia and Czech Republic 2005. 
not burdened with family responsibilities. If also confirms the entrepreneurship skills of the Polish women and their need for paid work.

Many women decide to start their own business out of choice and not out of necessity, as one's own company ensures independence in making decisions and self-determination. This is the escape from "glass ceiling" (for a woman the easier thing is to launch own business than to be promoted to a managerial position) ${ }^{19}$ and gender related discrimination ${ }^{20}$ provides a chance for obtaining high income, and at the same time facilitates combining work with family responsibilities and leisure.

\subsection{Part-Time Work, Teleworking and Other Forms of Women Employment - the Current Scale of the Phenomenon}

Poland, as well as the Czech Republic and Slovakia can be characterised by inflexible labour markets which are reflected inter alia in relatively low share of the part-time employed in the total number of the employed. The lowest rates of the part-time are typical for Slovakia where only $2.6 \%$ of the total number of the employed comprise persons working part-time ( $4.2 \%$ among women and $1.3 \%$ among men ). In the Czech Republic these shares are almost twice as high $-4.8 \%$ total $(8.3 \%$ among women and $2.2 \%$ men), while the highest shares of part-time work are in Poland: $11 \%$ of the total employment comprise part-time work $-14.5 \%$ in case of women and $8.4 \%$ in case of men (see Table 8).

Table 8

Part-Time Employment in Poland, the Czech Republic and Slovakia and Average for the EU (25), 2004

\begin{tabular}{|l|c|c|c|}
\hline Country & Total & Women & Men \\
\hline EU (25 countries) & 17.7 & 31.3 & 7.0 \\
\hline Czech Republic & 4.8 & 8.3 & 2.2 \\
\hline Poland & 11.1 & 14.5 & 8.4 \\
\hline Slovakia & 2,6 & 4,2 & 1,3 \\
\hline
\end{tabular}

Source: Eurostat, Labour Force Survey. Based on Situation of Women. International Comparisons, Report 13, p. 16; http://www.monitoring.rownystatus.gov.pl

In all European Union countries the share of part-time work is higher in population of women. Men are rarely employed part-time with the exception of Denmark where part-time employment rate is higher for men than for women. On the background of the average for 25 European Union countries, Poland, the Czech Republic and Slovakia are characterised by low part-time employment, particularly among women (e.g. in the Netherlands a significant majority of women - as much as $75 \%$ - work part-time, in

19 Glass ceiling is defined as invisible barriers of professional career of women and ethnic minorities. The presence of this phenomenon in the Polish conditions is indicated by the results of the surveys carried out by the IFiS PAN in 2002. See A. Titkow (ed.), Szklany sufit. Bariery i ograniczenia karier kobiet, Instytut Spraw Publicznych, Warszawa 2003.

20 This is indicated by B. Krug, Dyskryminacja kobiet: perspektywa neoinstytucjonalna, w: Ekonomia i płeć. Pozycja zawodowa kobiet w Unii Europejskiej, pod red. A.G. Dijkstra i J. Plantega,

Gdańskie Wydawnictwo Psychologiczne, Gdańsk 2003, p. 62. 
Germany, the United Kingdom, Belgium and Luxembourg - the rate amounts to about $40 \%$ in each).

Other flexible forms of employment, such as teleworking, job sharing or flexible time of starting and ending work are rare and are most often applied by large companies with foreign capital (e.g. Hewlett Packard, Xerox Poland) as solutions supporting combining work and family responsibilities. The surveys indicate that teleworking is applied in about $2 \%$ of the Polish enterprises. ${ }^{21}$

\section{The Future of Work and Women - Threats}

\subsection{The Decrease in Manual Work}

One must agree with J. Rifkin, ${ }^{22}$ that "the times of mass labour are ending"; in particular manual work has been decreasing due to the end of the industrial era in economy. New technologies replace simple jobs hitherto performed by people. Also, the agricultural sector is shrinking, where the large number of women used to find employment particularly in case of Poland. The era of knowledge-based society, including a development of the service sector, promotes educated people or the ones who continue their education and training. Therefore, among the unemployed middle aged women with low education level, are dominant; for such women leaving unemployment is relatively the most difficult. During the period of rapid industrialization with its enormous demand for labour, women with low qualifications were eagerly employed as manual workers in production lines, assembly lines or for packing products. Today the demand for such types of work has decreased due to highly mechanised production processes, therefore, women are being pushed off these jobs by men operating machines. Men with basic vocational education still find work easier than women with the same level of education; some occupations are in particular demand, such as construction workers, welders, electricians, plumbers, janitors, security guards, i.e. the jobs that are stereotypically associated with and have traditionally been performed by men for ages.

\subsection{Reduction of the Agricultural Sector}

In Poland - contrary to Slovakia and the Czech Republic - a large part of the society has been still employed in agriculture. The agricultural sector is dispersed and dominanted by small farms with low efficiency. They produce mainly for subsistence of a given household. The tendency in Europe is that agricultural sector needs increasingly less manpower in order to produce the same volume of production. This is due to a growing productivity and efficiency in this sector.

Among the total number of the self-employed in case of Poland, the majority comprise the agricultural farm owners (54\%: among men 51\% and among women

21 Based on W trosce o prace ..., op. cit, p. 91. The survey was carried out in 2001 by the Institute of Labour and Social Matters.

22 J. Rifkin, Koniec pracy. Schyłek siły roboczej na świecie i początek ery post industrialnej, Wyd. Dolnośląskie, Wrocław 2001. 
almost 59\%). Women who are owners of agricultural farms constitute over $40 \%$ of the total number of the population of farm owners; they dominate among the farms with the smallest area. Therefore, the negative impact of the reduction of the agricultural sector is mainly felt by women. The experience gained throughout maintaining an agricultural farm they may use in other form of economic activity as crafts sector, farm tourism, or selling agricultural products. ${ }^{23}$

In the Czech Republic and Slovakia the participation of agriculture is less significant than in Poland, therefore, this particular threat does not concern these countries.

\subsection{Stereotypes of Female and Male Roles}

The international surveys carried out by R. Siemieńska indicate that in Poland, as well as in the countries of the Central and Eastern Europe we deal with the general stereotype manifesting in the following conviction: in the situation of job shortages men have more rights for them than women. As much as $55 \%$ of the Polish society, the same share of the Czech, $42 \%$ - Hungarian, $40 \%$ - Russian, $29 \%$ - Slovenian agree with this opinion. For comparison, respective shares are: in Sweden only 8\%, in Denmark 11\%, in Finland $15 \%$, in Norway $-16 \%$, in the USA $-24 \%{ }^{24}$

However, it may seem that perceiving women as worse workers, less engaged in their work, as working only in order to supplement their husbands' earnings, in contemporary times is an anachronism and rare; the surveys show that employers and managers, as well as politicians and economic elites perceive women as not being sufficiently determined in action, less concentrated on work, reluctant to business trips and mobility or working overtime, therefore generally less available. Thus, female work is lower evaluated than male one, and is lower valued.

According to the stereotypical belief, women prefer work that is light, easy and clean. Therefore, if the employers encounter a women candidate for a job that does not reflect the stereotype, they do not consider her candidature in the recruitment process. The American surveys indicate that persons employed in male-dominated occupations more often than in the ones dominated by women describe their work as easy. ${ }^{25}$

There is generally believed that women are better suited for jobs related to caretaking, education, teaching. At the same time these jobs require higher qualifications and skills, as well as continuous learning, i.e. investment in human capital, high psychical resistance and responsibility. They may be described as difficult. However, these occupations are characterised by lowest salaries and their prestige has been gradually declining due to both: low pay, as well as feminization (which is positively correlated).

23 Por.: M. Parlińska, J. Sawicka, Społeczno-ekonomiczna sytuacja kobiet wiejskich w Polsce, w: Płeć a możliwości ekonomiczne w Polsce: czy kobiety straciły na transformacji? [Socio-economic situation of women in rural areas in Poland. O women lost because of transformation?], Raport Banku Światowego nr 29205, Warszawa 2004, p. 110-125.

24 R. Siemieńska, Nie moga, nie chcą czy nie potrafią? O postawach i uczestnictwie politycznym kobiet w Polsce, Wyd. Naukowe Scholar, Warszawa 2000, p. 130. Slovakia did not participate in this survey.

25 Cyt. za: C.M. Renzetti, D. J. Curran, Women, Men and Society, Wyd. Naukowe PWN, Warszawa 2005, p. 342. 


\subsection{Government Policy Supporting Traditional Roles of Women and Underdeveloped Institutional Forms of Childcare}

Government policy based on supporting the traditional roles of women (e.g. in Poland manifesting with introduction since 2006 of "becikowe", i.e. one-off childbirth benefit for all mothers regardless their material situation, or with attempts at lengthening the compulsory maternal leave only for women) consolidates stereotypes and does not facilitate occupational activation of women. It also does not solve demographic problems. The analysis of the statistical data from different countries shows that the duration of maternal leave does not influence the level of fertility (in the USA maternity leave has been established since 1993, it is not obligatory and is relatively short - up to 12 weeks $^{26}$, while fertility rates are higher than in Europe; in Sweden where there are numerous parenthood related facilities which concern both: mothers and fathers, fertility is higher than in Poland, in the Czech Republic, or Slovakia), whereas one-off benefits due to childbirth have short-term effects and encourages parents with lower education, and with difficult material situation, therefore those who are potential recipients of social welfare.

Underdevelopment of good quality and relatively cheap or even free of charge for parents institutional forms of childcare, as well as lack of generally positive attitude towards having children in the society (e.g. in a form of driveways for prams or low-deck busses, lifts in public places, tables for little children in restaurants), as well as in the working environment (e.g. kindergartens in enterprises, rooms for breastfeeding mothers, centres for children, subsidies for recreation and education) are the main reasons for low fertility. In the rapid changes economy women are "afraid" of having children, they do not want to lose work or they do not want to limit their chances for employment. At the same time, there is a general feeling that bringing up a child poses a big problem, as it requires overcoming many obstacles, investing a lot of means and time. Having children is competitive against other life matters (attaining education, earning, travelling, taking advantage of the wide opportunities offered by the contemporary world).

\subsection{Barriers of Entrepreneurship Development}

The lack of social acceptation for the private activity; lack of respect for entrepreneurship; lack of tradition in the field of education of the society towards entrepreneurship; fears of initiating changes in one's life comprise barriers of cultural character hindering in particular women's presence in business. Nevertheless, the first place in the hierarchy of barriers, the most often encountered by people launching their own business belongs to organizational barriers (e.g. large number of procedures concerning registration of one's own economic activity), then there are barriers related to the unclear principles of development of small and medium enterprises and unclear legal regulations. Therefore, the obstacles in starting own business are complicated together with changing procedures and excessive bureaucracy. The difficulties concerning lack of starting capital and financial means appear on the successive place.

26 Ibidem, p. 336. 
Training for people initiating their economic activity concentrates usually on providing the knowledge and skills concerning procedures related to starting own business. However, the experience of persons who provide assistance for entrepreneurs' beginners indicates that the most difficult for women are formalities connected with obtaining credit, getting necessary documents and vouchers. It is also important to offer a permanent assistance for those women who have already started their own economic activity. They should have opportunity to get necessary advice from the mentor supervising their activity during the beginning period of the business existence. Thanks to the special courses and individual assistance for the beginning women entrepreneurs it becomes possible to go through the complicated procedures related to a development of economic activity.

In the process of maintaining enterprises, the most serious problem for entrepreneurs pose high tax burdens. When establishing their own company, as well as in the course of its maintaining, the entrepreneurs have to struggle with the excessive number of administrative matters, difficult procedures, unclear legal regulations.

Comparing the frequency of indicating the barriers encountered by women and men entrepreneurs indicates some regularity. Women less often than men mention barriers connected with starting economic activity (with the exception of credit access), while more often than men they meet difficulties concerning maintaining and developing own business. The difference is particularly obvious in respect to barriers as unclear legal regulations and strong competition - women indicate them evidently more often than men. ${ }^{27}$ There is a significant share of entrepreneurs declaring problems related to lack of knowledge of the tax law. Many admit insufficient knowledge about bookkeeping and accountancy, labour law, economy, and civil law. The lowest number of people declares problems related to the lack of knowledge concerning the branch they operate in. ${ }^{28}$

Both men and women entrepreneurs usually believe that men possess greater predispositions for managing enterprises. The following opinions sum up for this: "men are more resourceful, operative, pushier, energetic, stress resistant, communicative, versatile, effective, they are harder and posses a knack for business". Such opinions confirm the presence of gender related stereotypes, according to which only men are gifted with attributes that are components of entrepreneurship.

Perceiving one sex as the being less predisposed to entrepreneurial activities, erects a barrier in making decisions concerning self-employment by women. It is the more difficult for overcoming as it aims at self-perception of women shaped in the process of socialization and was influenced by social relations and occurrences.

27 Por.: Bariery przedsiębiorczości kobiet. Raport z badań przeprowadzonych przez Ipsos Demoskop w 2001 r. na zlecenie Polskiej Agencji Rozwoju Przedsiębiorczości [Barriers of Women's Entrepreneurship. Report on the survey carried out by the IPSOS Demoscop for the Polish Agency for Development of Entrepreneurship], Warsaw 2001.

28 Ibidem. 


\subsection{Low Level of Education and Qualifications of Women of an Older Age}

Low level of education of women of an older age constitute the most significant barrier of their occupational activation and it enforces the use of the privilege for the earlier retirement or receiving social welfare benefits.

In all three analysed countries, lifelong learning is not a standard and it has not been widely popularized in the society. About 5\% of women aged 25-64 (in the Czech Republic slightly over 5\%, in Poland and Slovakia - less than 5\%) participated in any form of education in 2004, while the respective rate for Denmark was 23\%, Finland $21 \%$, and Sweden $32 \%{ }^{29}$ Participation in lifelong learning decreases with age, i.e. among women at older age their participation in education is exceptional. Such women concentrate rather on the possibility to take advantage of the earlier retirement or disability pension, if they have such possibilities, than on achieving new skills or qualifications that would facilitate continuation of their career.

\section{The Future of Work and Women - Chances}

\subsection{Wide Development of Services, including New Technologies}

The importance of services in economy has been significantly growing. A development of the service sector is determined by the level of education of the society. The higher is this level, the more frequent is economic activity of population, including also women, the higher are household incomes and the more frequently they take advantage of various types of services. On the other hand, people employed in services are usually better educated, particularly in business related services.

All three presented countries still have low participation of the service sector in the in the structure of economy as compared with the average for the old EU countries. Therefore, in the following years, services will be developing the most dynamically in these countries. Therefore, there are chances for employment of women, considering that according to the example of the developed countries, more women than men are employed in services. Moreover, popularization of intellectual work provides chances for women, as - according to F. Fukuyama - "the economy of the information age transforms manual work into intellectual one and in such world women by nature have a greater role to play". ${ }^{30}$ The physical efforts are by nature associated with men and their physical strength. Women, since the very beginning of their entrance into the labour market have been employed in the office work and the one not requiring a lot of physical strength. Even if they worked in the production lines it was the monotonous and strenuous work, although not requiring particular physical efforts. Automation and computerization make work less hard, easier, cleaner, based on manual abilities, attentiveness and meticulousness, which attributes more often characterise women. Creativity and ability to form good relations with other people comprise fundamental element of intellectual work; these abilities are close to women.

29 Europe in Figures, Eurostat Yearbook 2005, p. 104.

30 F. Fukuyama, Wielki wstrząs. Natura ludzka a odbudowa porządku społecznego [The Great Disruption], Bertelsmann Media, Warszawa 2000, p. 102. 
New technologies are created for women. Moreover, they are not biased with gender stereotype. Therefore, women should eagerly enter all fields that are connected to new technologies, including also establishment of their own companies based on the new technologies. Some branches of the Western companies are willing to employ women and they have special implementation programmes for them, e.g. IBM, Hewlett Packard or General Electric.

\subsection{Self-Employment as the Alternative Form of Work for Women}

High unemployment among women may be fought through stimulation of their entrepreneurship, encouraging self-employment and creation of jobs not only for themselves, but for other women as well. There is a need for the concrete programmes to support educated unemployed women who show interests in starting their own small businesses. There are needed the centres where women may obtain information, advice and technical support in a form of short training, as well as a small loan or credit vouching, in order to be able to get higher bank credit.

Establishing the centres for promotion of entrepreneurship among women lies in the interests of municipalities, as it will serve the future perspective of local community development, it lowers local unemployment, it creates chances for development of the citizens' society. The centres for promotion of entrepreneurship could be established by women for women within the framework of the non-profit activities. Financial means for the projects promoting entrepreneurship among women and preparing them for launching their own companies may be obtained from the European Social Fund.

\subsection{Reduction of Prejudices and Discrimination}

Among the priority objectives of the European Union policy is achievement of equal chances for women in access to employment, the process of promotion and training, as well as in equal pay for work of the same quality. The European Union is focused on achievement of a growth in employment of all social groups, including those that are discriminated on the labour market (women, the disabled, the elderly). Therefore the Lisbon strategy has been adopted. The Strategy assumes the increase in employment of women and men and people aged 55 years or more. The governments of particular Union countries were obliged to initiate efforts towards finding solutions facilitating the growth in the number of the employed.

In 2001 the Community Initiative EQUAL was announced, which was carried out within the framework of the second phase in 2004, in order to provide the New Member States with the chances to take advantages from the financial opportunities in the field of combating discrimination on the labour market against different social groups or categories. EQUAL characterises the international contexts of its projects, which facilitates development of new tools or innovatory approach to solving the problem which poses inequality in the access to the labour market. Created within the EQUAL framework "Partnerships for Development" it constitutes a laboratory of searching for and testing the innovative methods aimed at achievement of the objectives written in the European Employment Strategy and incorporated in the Process of Social Integration. Throughout the active international cooperation of the Member States exchanging of 
experience and good practices the process of popularization of the best and innovative solutions has been carried out. Those practices were proved as effective in combating various forms of discrimination and inequalities, both against employed persons and those who are seeking work.

One of the five priorities of EQUAL is equality of chances for women and $\mathrm{men}^{31}$, and within this reconciliation of family and occupational life and reintegration of persons who left the labour market through development and promotion of flexible forms of employment and organization of work in enterprises. Other priorities are local development, development of the information society, sustainable development, promoting good multicultural relations, providing assistance for the victims of human trafficking. By the decision of the Member States, the topics defined in the first phase of EQUAL were sustained in the second phase. They are following:

Topic A. Facilitation of entering and re-entering the labour market of those who have problems with integration and reintegration on this market, in order to promote the labour market open for all.

Topic B. Combating racism and xenophobia in the workplace.

Topic C. Ensuring the general access to own economic activity through providing necessary tools for setting own business and for identification and utilization of new possibilities for creating jobs in urban and rural areas.

Topic D. Strengthening national social economy (third sector), in particular the services for local populations and improvements in quality of jobs.

Topic E. Supporting lifelong learning and integrative forms of work organization facilitating employment and maintaining employment by persons suffering discrimination and inequalities on the labour market.

Topic F. Supporting capabilities of enterprises and employees to adjustment to structural changes in economy and utilisation of new information technologies and other new technologies.

Topic G. Reconciliation of family and occupational life and reintegration of men and women who left the labour market, through implementation of more flexible and effective form of work organization and accompanied services.

Topic H. Reduction of inequalities in treatment of both sexes and preventing occupational segregation.

Topic I. Assistance in social and occupational integration of people applying for the status of refugee. ${ }^{32}$

Poland accessing the second phase of IW EQUAL chose the topics A, D, F, G, I (altogether 107 projects were accepted for implementation). The Czech Republic - all topics (59 projects has been carried out there), while Slovakia - topics A, B, D, F, H, I (99 projects has been carried out). ${ }^{33}$ All projects within the framework of the

31 According to the Article 1 of the Regulation EC No. 1260/1999 of 21 June 1999, defining general provisions concerning structural funds (Journal of Laws No. L 161/1 of 26.06.1999), promoting equality between women and men is the integral element of all subjective fields, moreover, it is the objective of special actions.

32 Based on the Programme of Community Initiative EQUAL for Poland, the Ministry of Economy, Labour and Social Policy, Warsaw, April 2004, p. 5.

33 Information comes from the projects carried out in the second phase CI EQUAL, presented on the website https://equal.cec.eu.int/equal/jsp/index. 
Community's Initiative EQUAL characterise partnership approach (many partners) and subjective (inserting into a one of the topics), they are innovative, are based on the international cooperation, engagement of the groups discriminated against (the rule of empowerment) and including the results into the main stream (the rule of mainstreaming).

Reduction of prejudices and discrimination begins with law, which is followed by controlling and institutional mechanisms. Introduction of legal regulations equalising chances of women in the USA, such as, e.g. Civil Rights Act of 1964, Equal Credit Opportunity Act of 1975, or Affirmative Action of 1978, as well as creation of the centres for women within the framework of the state Agency of Small Business Administration had direct influence on the growth in women's wages and salaries, the increase in their participation among managers, and the increase in the women's interest in starting their own businesses. ${ }^{34}$ The Scandinavian countries also present a good example for the role of the consequent state policy in establishing the real equality of women and men in the society and workplace. At the same time, all of the above mentioned countries have one of the highest rates of female economic activity and high fertility rates.

\subsection{Development of Flexible Forms of Employment}

Various forms of flexible employment will be popularised on the wide scale in the United States in the nearest future. There are already evident symptoms of the new tendencies consisting in reduction of the scale of full-time work; the stable jobs in large enterprises also belong to the past, average professional career comprises a couple of jobs performed for many employers; the self-employment and other atypical forms of work have been widely spreading; the office and administrative jobs are becoming scarce because of computerization; increasingly more often is order-agreement employment, or employment within the framework of projects. ${ }^{35}$

In Poland, as well as in Slovakia and the Czech Republic there is still observed the strong attachment to the full-time employment, among both, the employees and the employers. Therefore, these countries still face the task of making the labour market more flexible, which in further perspective will offer opportunities to women, as hither they more often than men have been choosing these forms of employments because they facilitate reconciliation of work and family responsibilities. There is a need for legal regulations which firstly would allow a wide range of flexible forms of work for women and men alike, and secondly, would prevent worse working conditions than those of the employed full-time, e.g. the same pay per one hour for work full- and part-time, and the same privileges for working part-time as in case of full-time workers. The increasing productivity of societies will allow higher remuneration, including also the pay of the part-time employed. This will eliminate worries of women and trade unions related to the poorer treatment of part time workers.

34 C.G. Brush, Women-Owned Businesses: Obstacles and Opportunities, "Journal of Development Entrepreneurship" 1997, Vol. 2, No 1, p. 5.

35 T. Peters, Biznes od nowa [Re-imagine], Wyd. Studio EMKA, Warszawa 2005, p. 235-247. 
In case of the new, flexible employment it is also important to promote them in the society and convince people that there are already many jobs available which can be performed as teleworking, from their homes with the use of a computer and Internet.

\subsection{Education of Women and their High Participation among Tertiary School Students}

The key achievement of women in 20th century was gaining access to education at all levels and in all fields. Because of that, women were able to enter the labour market and find their permanent place there. Thanks to education women entered the typically male occupations and fields, e.g. law, construction, security guards. The access of women to higher education resulted in their higher participation among tertiary school students and graduates. The formally high qualifications of women give them chances in their attempts at gaining managerial positions, including the top executive ones.

Tom Peters - recalling the results of the studies and analyses carried out by the American anthropologist Helen Fisher - states that women are better suited for leadership than men, that they decidedly better win people's trust than men. Women make better salespersons and investors, they push forward, i.e. they participate in education and training and are open to changes, they possess talents necessary for the new economy. New economy prefers women, because they pay less attention to hierarchy than men, they make contacts more easily and they sustain their relationships, they more often cooperate than compete. "The talent of women is simply our brilliant chance. The occasion knocking at our doors... I shall employ women ."

\subsection{Development of the Citizens' Society (the third sector)}

The democratic system is characterised inter alia with the consent for development of the citizens' society. The citizens initiate various associations, foundations, non-profit institutions that are established for solving the specific problems of the local, small or discriminated individuals against social groups.

The experience indicates that women more often find work in this sector than men. Women generally seek alternative forms of employment, as their situation on the formal labour market is more difficult than men's. Moreover, skills and experience of women are very useful in providing service on behalf of other people. Thus, when there are no restrictions for this sector development, the chances for the jobs for women increase. Potentially, this sector is enormous - culture, arts, sport, recreation, religion, taking care of the elderly, environment protection, citizens' matters (e.g. amicable settlement of arguments).

36 T. Peters, Biznes od nowa, op. cit, p. 271 See also H. Fisher, Pierwsza płeć. Jak wrodzone talenty kobiet zmienią nasz świat [The First Sex. The Naturals Talents of Women and How They Are Changing the Word], Wyd. Jacek Santorski i Spółka, Warszawa 2003, p. 33-86. 


\subsection{Dual Way of Women's Self-Realization}

Within the framework of the traditional patriarchal society, a division of roles into feminine and masculine was established. Quite recently (as late as the mid-fifties of the twentieth century) this division constructively influenced recreation of societies. The liberalism of the most affluent countries and women's leaving home and entering work enforced numerous adjustments in the systems of social services, in order to allow parents combining work with parental responsibilities. So far, women have been potentially more willing to make changes, since the escape from patriarchat burdens mainly them with additional responsibilities (work, maintaining a household, chilcare). Woman had to undergo transformation from being specialized in childcare and household to the one specialized in many important domains. At the same time it turned out that it is difficult to combine all these functions and still remain good in every field without a harm to one's own health and efficiency, and in the social dimension - without a reduction of procreative potential.

It seems that in the future we will observe crystallization of a dual way of women's self-realization. Some of them will want mainly to look after their family and maintain their households, while the others will consider work and career as the most important. The first group's priority will be having children, they will treat occupational activity as the one with minor priority - as the way to obtain casual income, and after their children grow up as securing even a minimal retirement allowance. For the second group, paid work and obtaining high incomes will be an objective superior to having children.

The mentioned dualism will become more obvious when housework and care-related tasks are valuated through including their value into the in national income or to the retirement pension system.

\subsection{Important Future Skills}

The surveys indicate that education in transition countries is not adjusted to the changes that are occurring in the global economy leaping towards knowledge based economy. The pupils and students receive too much information (facts) that they have to memorize; on the other hand, they do not have enough practice in understanding texts, asking questions, independent thinking and problem solving, as well as in acquiring skills necessary in everyday life (e.g. how to use credit and parking cards, mobile phones, computer, pin number and electronic bank account). ${ }^{37}$ They also do not learn how to take advantage of knowledge resources, i.e. they do not learn how to learn, which skill is the most important in the era of rapid changes. Art and music are unwisely removed from schools.

The following skills may be already included in the canon of the future education as stated in the book The Grains of Greatness - Ten Best Guarded Secrets by D. Waitley:

37 The mentioned surveys are carried out periodically within the framework of the International Programme of Pupils (Students) Evaluation OECD/PISA on representative samples in over 40 countries. The conclusions come from the survey conducted in 2000 (see I. Białecki, Educaction for Development, in: the White Book 2004. Polish Forum of Lisbon Strategy, Gdańsk-Warsaw 2004, pp. 226-227). 
1. Ability to communicate in writing and verbally

2. Ability to analyse a problem pointedly and thoroughly; focusing on its solution

3. Effective use of computer and Internet

4. High self-motivation and lifelong learning

5. Taming risk and openness to constant challenges

6. Lack of fear of making a mistake and treating failures as valuable experience

7. Honesty

8. Passion and involvement

9. Assuming personal responsibility for own life

10. Creativity and entrepreneurship. ${ }^{38}$

Some of these skills may be achieved during school education, however, one must think of training and lifelong learning in order to be able to follow up the changes generated by technological changes. At the same time, these skills are close to womentheir way of thinking and habits established during the evolutionary process. Communicative skills, high motivation and learning aspiration, aversion to hierarchy and ability to cooperate and forming teams, and finally, honesty, passion and involvement are attributes very often possessed by women. They may be freed with ease in favourable conditions.

\section{Conclusion and Thesis for Discussion}

Do we deal with the tendency of work "escape" and its end? Are women more or less threatened with lack of work in the future than men? Will the twenty first century favour improvement of chances for women?

Generally, we may accept the thesis that a great challenge for the societies poses rapid socio-economic changes characterised inter alia with a dynamic growth of knowledge and information, ease of communicating over the borders of countries and continents, replacement of manual labour with robots, and replacement of office work with computers, domination of the market over social policy, increasing life span, and low fertility in the developed countries.

Aspiring to freedom crashes with the necessity of to standarize (regulate) the growing number of human behaviours in order to provide them with attributes safe for the development of the societies and individuals. We still perceive the lack of the worlds order, as well as the lack of order serving the well-being of all citizens within some countries. We still do not know how to take advantage of freedom and democracy in a responsible way.

Insufficient use of the potential of women who constitute a half of the population of every country, throughout confining them within their stereotypical social roles, is a great waste. Women possess talents that should be used in business, as well as in politics. "I can imagine a woman in the White House" - states Tom Peters. Women are characterised by responsibility, they can see matters in their wide social context, they value intuition, as well as rationalism, they are ready to accept unclear situations, they can see many options and possible results, they are flexible and tolerate cultural

38 Elaborated on the basis of the D. Waitley's lecture of and his book; Seeds of Greatness, The Ten Best-Kept Secrets of Success, published by Studio EMKA, Warsaw 2005. 
differences. In the best interests of every society as a whole (not only the individuals who are interested) lies a growth in women's participation in economic and political life, particularly at the place where the decisions are made.

There are many things to do, there will be enough work for many future generations, for men and women alike, but this is mainly intellectual work. One should agree with the authors who claim that we are facing the end of the industrial era and are moving to the era of information and knowledge. The demand for manual work is increasingly smaller (and it is a permanent tendency), on the other hand, the demand for intellectual work is growing. Development of the new technologies generates very fast changes, it destroys old principles, and it is accompanied by numerous failures which should be adjusted, it requires flexibility of behaviour from people.

Thanks to technological progress, new forms and place of work have been developed: fast development of small enterprises, often virtual ones, teleworking, i.e. providing services via home computer, development of tourist, recreational facilities and catering, psychoterapeutic, consulting and many other kinds of services. Large companies do not have a chance to stay on the market. Particular sections will be leaving them and establishing small service oriented companies. Micro-enterprises will be developing, temporary work will be popularised (even today in the USA the greatest private employer is Manpower Inc. - a huge temporary work agency ${ }^{39}$ ), free-lance and project will also become widespread.

These changes concern women and men to the same extent. However, women are even today better prepared for these changes, as they are better educated, they have motivation towards taking up challenges, and they possess skills that are needed in contemporary business (ability to communicate, cooperate, expresss emotions, appreciate esthetics and values of experience). Therefore, the twenty first century will favour women. Even today women make most of consumers' decisions, their number in management and power structures is growing. We can quote Helen Fisher that in the future women will change the world into the place more friendly for both sexes.

\section{References}

Fisher, H. (2003), Pierwsza płeć. Jak wrodzone talenty kobiet zmienią nasz świat. Warszawa : Jacek Santorski i Spółka.

Fukuyama, F. (2000), Wielki wstrząs. Natura ludzka a odbudowa porządku społecznego. Warszawa : Bertelsmann Media.

Kotowska, I.E. (2004), „Proces starzenia się ludności Polski do 2030 r. - opis i jego percepcja społeczna, w: Później na emeryturę?" Niebieskie księgi, Rekomendacje nr 16, Gdańsk : Instytut Badań nad Gospodarką Rynkowa.

Krug, B. (2003), „Dyskryminacja kobiet: perspektywa neoinstytucjonalna, w: Ekonomia i płeć. Pozycja zawodowa kobiet w Unii Europejskiej." Dijkstra A.G., Plantega, J., Gdańsk : Gdańskie Wydawnictwo Psychologiczne.

Lazar, I., Darlington, R. (1982), "The Lasting Effects of Early Education: A Report from the Consortium for Longitudinal Studies." Journal of the Society for Research in Child Development, No 47.

Lisowska, E. (2001), „Przedsiębiorczość kobiet w Polsce na tle krajów Europy Środkowej i Wschodniej." Monografie i Opracowania nr 494, Warszawa : Szkoła Główna Handlowa.

39 T. Peters, Biznes od nowa [Re-imagine], Wyd. Studio EMKA, Warsaw 2005, p. 237. 
Parlińska, M., Sawicka, J. (2004), „Społeczno-ekonomiczna sytuacja kobiet wiejskich w Polsce, w: Płeć a możliwości ekonomiczne w Polsce: czy kobiety straciły na transformacji?" Raport Banku Światowego nr 29205, Warszawa.

Peters, T. (2005), Biznes od nowa. Warszawa : Studio EMKA.

„Płeć a możliwości ekonomiczne w Polsce: czy kobiety straciły na transformacji?” Raport Banku Światowego nr 29205, Warszawa, 2004.

Renzetti, C.M., Curran, D.J. (2005), „Kobiety, mężczyźni i społeczeństwo.” Warszawa : Naukowe PWN.

Rifkin, J. (2001), „Koniec pracy. Schyłek siły roboczej na świecie i początek ery post industrialnej.” Wrocław : Dolnośląskie.

Siemieńska, R. (2000), „Nie moga, nie chcą czy nie potrafią? O postawach i uczestnictwie politycznym kobiet w Polsce." Warszawa : Naukowe Scholar.

Stoyanovska, A. (2001), “Jobs, Gender and Small Enterprises in Bulgaria, Series on Women's Entrepreneurship Development and Gender in Enterprise." Working Paper No 20, International Labour Office, Geneva.

Sztanderska, U. (2004), „Rynek pracy dla konkurencyjnej gospodarki.” Biała Księga 2004, Polskie Forum Strategii Lizbońskiej, Gdańsk-Warszawa, maj 2004.

Titkow, A. (red.) (2003), „Szklany sufit. Bariery i ograniczenia karier kobiet.” Warszawa : Instytut Spraw Publicznych.

Titkow, A.D. (2004), „Duch-Krzysztoszek, B. Budrowska, Nieodpłatna praca kobiet. Mity, realia, perspektywy." Warszawa : IFiS PAN.

„W trosce o prace, Raport o rozwoju społecznym." Polska 2004. Warszawa : UNDP.

Waitley, D. (2005), „Ziarna wielkości. Dziesięć najlepiej strzeżonych tajemnic sukcesu.” Warszawa : Studio EMKA.

„Wzrost, zatrudnienie i standardy życia w Polsce doby akcesji.” Raport nr 28233-POL, Bank Światowy, Warszawa 2004. 